\title{
Determinants of Health Service Efficiency in Hospital: A Systematic Review
}

\author{
Berly Nisa Srimayarti*, Devid Leonard, Dicho Zhuhriano Yasli \\ Department of Hospital Administration, STIKES Dharma Landbouw, Padang, Indonesia \\ *Corresponding author E-mail: berlynisasrimayarti@gmail.com
}

Manuscript received 15 April 2021; revised 1 May 2021; accepted 15 June 2021. Date of publication 3 July 2021

\begin{abstract}
One of the benchmarks for assessing service performance in hospitals is efficiency in medical services. Measurement of service efficiency will affect the quality of the hospital. Patients will consider the completeness of the service facilities they have and the quality of services to be obtained. This is due to the tendency of people to seek quality health services. Improving service quality standards in hospitals will have an impact on increasing income and getting recognition from the community for the quality of services in hospitals. This study aims to look at the determinant factors that affect hospital efficiency. This study uses a systematic review method based on the PRISMA protocol. Article searches were conducted through four online databases (PubMed, ProQuest, SAGE and SpingerLink). The initial search found 307 articles, filtered using inclusion criteria, so as many as 8 articles were analyzed with a time span of 2017-2021. The efficiency of health services in hospitals is the basis for obtaining a wider patient base and producing quality services. The results of the literature study show that there are 29 factors affecting hospital efficiency. The various factors obtained were categorized into organizational factors, health resource factors, and technical efficiency factors.
\end{abstract}

Keywords: hospital, efficiency, health services, service quality

\section{Introduction}

The hospital as one of the complex health care facilities, because it involves various functions of service, education, and research, and covers various levels and types of disciplines so that hospitals are able to carry out professional functions both in the medical technical field and health administration to maintain and improve the quality of the home Hospitals must have a measure that ensures quality improvement at all levels [1]. A hospital is a health service institution that provides complete individual health services that provide inpatient, outpatient, and emergency services [2].

One of the benchmarks for service in hospitals is efficiency in medical services. The implementation of hospital efficiency is not only related to aspects of medical administration, but also aspects of administrative management. The hospital efficiency assessment basically assesses the efficiency of medical services related to the utilization of available beds in the hospital and the efficiency of the utilization of hospital medical support. One of the hospital efficiency assessments can use the Barber Johnson chart. The Barber Johnson chart as an indicator of hospital management is a knowledge that has not been widely informed and seems to be needed by hospital managers in planning and policy making, in addition the Barber Johnson chart is one of the prerequisites for assessment by the Hospital Accreditation Team [3].

Quality health services are health services that can meet the needs felt by patients and are carried out in a good, timely, responsive and able to cure their complaints and prevent the development or spread of disease [4]. In addition, in choosing a hospital, patients will consider the completeness of the service facilities they have and the quality of service to be obtained. This is due to the tendency of people to seek quality medical services.

Based on previous research conducted by Respati, related to the use of the Barber Johnson concept in developed countries it is used in hospital management to assess the efficiency of care management. This concept requires an orderly recording and reporting system as well as an attitude to assess his recovery. Based on the ideal standard of the four Barber-Johnson indicator parameters internationally, namely Bed Occupancy Rate (BOR) 75-85\%, Length of Stay (LOS) 3-12 Days, Turn Over Interval (TOI) 1-3 days, and Bed Turn Over (BTO) 30 times a year. Meanwhile, according to the Ministry of Health in 2005, the efficiency of the use of beds if the BOR rate ranges from 65-85\%, LOS 6-9 days, TOI 1-3 days, and BTO 40-50 times in a year [5]. BOR and BTO are indicators used to assess the service coverage of inpatient units, while LOS and TOI are indicators used to assess the efficiency of medical record unit services [6]. 
Based on the explanation above, researchers are interested in conducting a systematic review, through this method researchers can see and compare hospital efficiency through previous studies from various countries. This study aims to look at the determinant factors that affect hospital efficiency.

\section{Literature Review}

Hospital is a health service institution that provides complete individual health services that provide inpatient, outpatient, and emergency services. Hospitals have the task of providing complete individual health services, which are related to health services which include promotive, preventive, curative and rehabilitative. One of the principles of service in hospitals is efficient service [7]

Efficiency is one of the performance indicators that theoretically underlies all hospital performance. Efficiency can be used to allocate resources more precisely on target so that the resources that come from shareholders can be utilized optimally. Assessment of service efficiency is an assessment of managerial ability in the context of processing human resources, sources of funds, equipment, and technology, in order to provide health services to patients. Efficiency is related to 3 things, namely indicators and criteria, achievement of the assessment, and determining the level of efficiency [8].

Availability of hospital beds and efficiency in the management of health resources play an important role in determining the maneuvering room for health facilities in the event of an emergency [9]. Various studies identify factors to look at efficiency, such as hospital size, own-ership, bed occupancy rate, outpatient to inpatient ratio, average income of the population, technology, financing, and hospi-tal teaching status as determinants of hospital efficiency [10].

\section{Methods}

The method used in this study is a systematic review, in which several search strategies are used to identify relevant studies, carried out systematically consisting of identification, selection, assessment, and synthesis of the research results [11] [12]. The systematic review was based on PRISMA from the 2009 flow chart, and was selected according to the inclusion criteria of the study [13]. A systematic search was conducted to identify article eligible articles in electronic databases, including: PubMed, SAGE, SpingerLink, and ProQuest [14] [15].

\subsection{Inclusion Criteria}

The inclusion criteria consist of: restriction criteria related to the type of English, documents deemed appropriate are as follows: journals, articles, original studies, conference papers, full and free downloadable documents, published from (2017-2021), health disciplines, medicine \& public health, health administration, and health informatics.

\subsection{Document Selection Based on Keywords}

The following are the details of the search strategy carried out through 4 online databases: Search on the PubMed database as follows ((Efficiency) AND (Hospital Occupancy)) AND (Bed Utilization), Some of the inclusion criteria are the sub-disciplines used by public health, health administration, health informatics, nursing research, documents available for free full text and publication period 2017 2021. Search on the Proquest and Springerlink database as follows Efficiency AND Hospital Occupancy AND Bed Utilization. And then search on the SAGE database as follows [All efficiency] AND [All hospital] AND [All occupancy] AND [All bed] AND [All utilization].

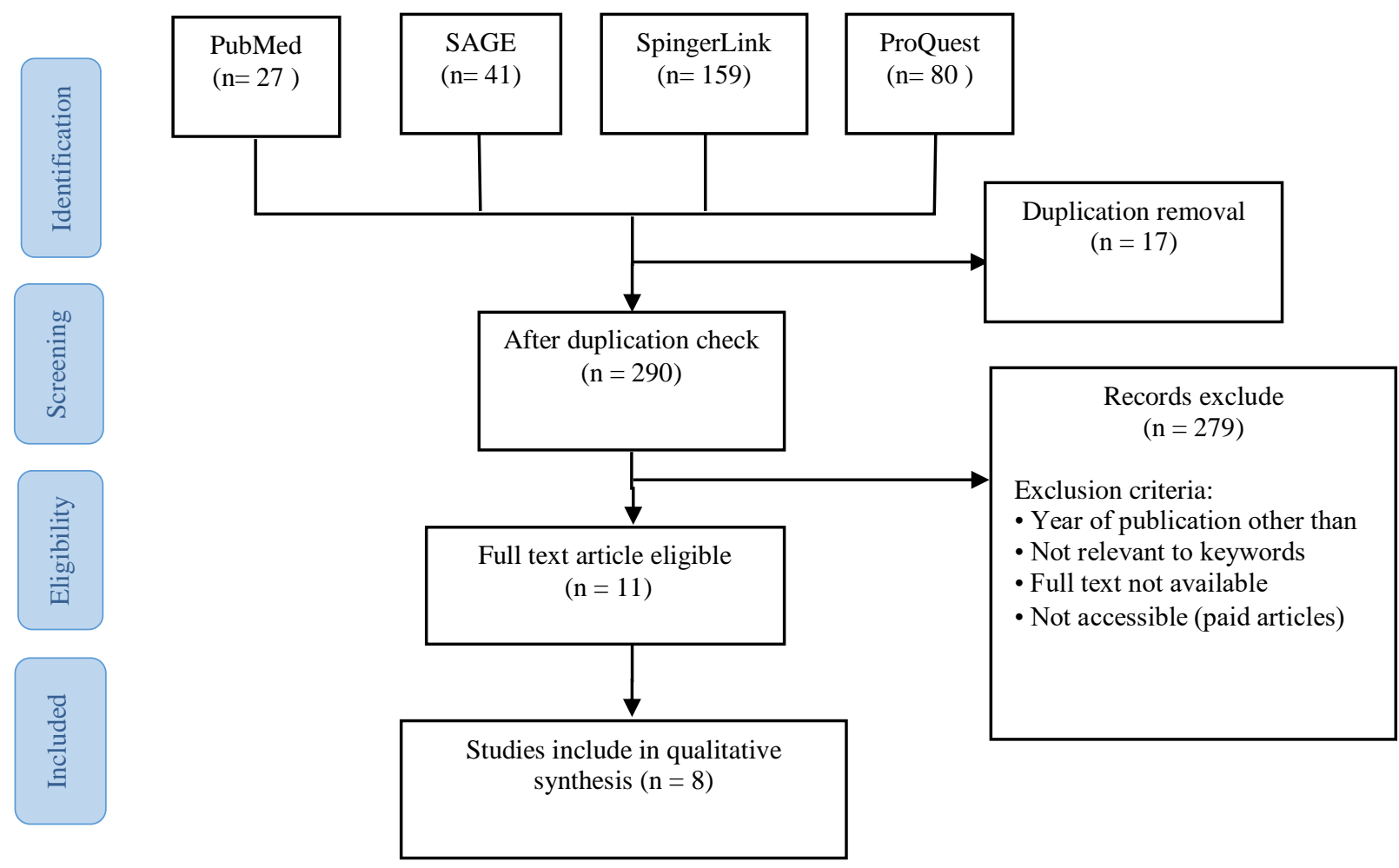

Fig 1. Flow chart of study selection process 


\section{Result and Discussion}

Researchers identified 8 articles that met the inclusion criteria. Some of these studies were carried out in several countries, namely Iran, America, Palestinian, Tureky, Indonesia, Southeast Nigeria, and Uganda. The research design used in each of these articles is 2 articles using Data Envelopment Analysis (DEA) models, a longitudinal cross sectional study, cross-sectional study, descriptive, gray relational method (parametric statistical analysis methods), and descriptive method with a qualitative approach, and Tobit Regression Model. Table 1 is a table that describes the characteristics of the 8 articles analyzed, which are as follows:

Table 1. Characteristics of Included Articles

\begin{tabular}{|c|c|c|c|c|c|c|}
\hline No & Title & Year & Country & Results & $\begin{array}{c}\text { Factors Affecting Hospital Effi- } \\
\text { ciency }\end{array}$ & Conclusion \\
\hline 1 & $\begin{array}{l}\text { Assessment of } \\
\text { the Efficiency of } \\
\text { Hospitals before } \\
\text { and after the } \\
\text { Implementation } \\
\text { of Health Sector } \\
\text { Evolution Plan in } \\
\text { Iran Based on } \\
\text { Pabon Lasso } \\
\text { Model [16] }\end{array}$ & 2017 & Iran & $\begin{array}{l}\text { Hospital performance analy- } \\
\text { sis showed an increase in the } \\
\text { average bed occupancy and } \\
\text { turnover ratio, during the } 12 \\
\text { months after HSEP, from } \\
65.40 \% \text { and } 86.22 \\
\text { times/year to } 69.97 \% \text { and } \\
90.98 \text { times/year, respective- } \\
\text { ly. In line with the Pabon } \\
\text { Lasso model, before the } \\
\text { implementation of HSEP, } \\
27.27 \% \text { and } 36.36 \% \text { of hos- } \\
\text { pitals were entirely efficient } \\
\text { and inefficient, while after } \\
\text { the implementation of HSEP } \\
\text { the conditions changed to } \\
18.18 \% \text { and } 27.27 \% \text {. }\end{array}$ & $\begin{array}{l}\text { 1. BTO } \\
\text { 2. BOR } \\
\text { 3. ALS }\end{array}$ & $\begin{array}{l}\text { Indicators of bed occu- } \\
\text { pancy and turnover ratio } \\
\text { had a } 4 \% \text { increase in the } \\
\text { studied hospitals after } \\
\text { the implementation of } \\
\text { HSEP. More than } 50 \% \\
\text { of the hospitals in the } \\
\text { studied province have } \\
\text { not yet reached their } \\
\text { optimal bed occu-pancy } \\
\text { ratio (more than } 70 \% \text { ), } \\
\text { strategy for improving } \\
\text { the efficiency is to stop } \\
\text { further expansion of } \\
\text { hospitals as well as de- } \\
\text { veloping the number of } \\
\text { hospital beds. }\end{array}$ \\
\hline 2 & $\begin{array}{l}\text { A robust analysis } \\
\text { of hospital effi- } \\
\text { ciency and fac- } \\
\text { tors affecting } \\
\text { variability [17] }\end{array}$ & 2017 & American & $\begin{array}{l}\text { Non-profit, fully integrated } \\
\text { and education hospital is } \\
\text { more efficient } \\
\text { than others, and hospitals } \\
\text { located in more competitive } \\
\text { markets are more efficient } \\
\text { than those located in low } \\
\text { competitive markets. }\end{array}$ & $\begin{array}{l}\text { Organizational factors, such as: } \\
\text { 1. Hospital-physicians integration } \\
\text { level, } \\
\text { 2. Teaching status, } \\
\text { 3. Market competition } \\
\text { 4. Status technology level } \\
\text { 5. Medicaid admissions medicare }\end{array}$ & $\begin{array}{l}\text { Hospitals in less compet- } \\
\text { itive markets need to } \\
\text { increase their efficiency } \\
\text { level, and the integrated } \\
\text { role of doctors also } \\
\text { greatly determines hos- } \\
\text { pital efficiency. }\end{array}$ \\
\hline 3 & $\begin{array}{l}\text { Measuring the } \\
\text { efficiency of } \\
\text { Palestinian pub- } \\
\text { lic hospitals dur- } \\
\text { ing 2010-2015: } \\
\text { an application of } \\
\text { a two-stage DEA } \\
\text { method [18] }\end{array}$ & 2018 & $\begin{array}{l}\text { Palestini- } \\
\text { an }\end{array}$ & $\begin{array}{l}\text { Four predictors explaining } \\
\text { the inefficient performance } \\
\text { of a hospital (p }<0.01) \text { are: } \\
\text { bed occupancy rate (BOR); } \\
\text { the outpatient-inpatient ratio } \\
\text { (OPIPR); hospital's size } \\
\text { (SIZE); and the availability } \\
\text { of primary healthcare cen- } \\
\text { ters within the hospital's } \\
\text { catchment area (PRC). }\end{array}$ & $\begin{array}{l}\text { 1. Managerial efficiency (practic- } \\
\text { es) } \\
\text { 2. External operating environment } \\
\text { (operational conditions) } \\
\text { 3. The size of the hospital } \\
\text { 4. Bed occupancy rate (BOR) } \\
\text { 5. Outpatient - inpatient ratio } \\
\text { (OPIPR) } \\
\text { 6. The average length of stay } \\
\text { (ALOS) } \\
\text { 7. The ratio of administrative to } \\
\text { health employees. (ADHR) } \\
\text { 8. Hospital size (dummy) } \\
\text { 9. Hospital location (dummy) } \\
\text { 10. The proportion of refugees } \\
\text { living in the governorate. } \\
\text { (REFP) } \\
\text { 11. Number of hospital beds per } \\
\text { 10,000 inhabitants (HPFP) } \\
\text { 12. The available primary care } \\
\text { centers per 10,000 inhabitants } \\
\text { (PRC) } \\
\text { 13. The percentage of public hospi- } \\
\text { tal beds (PPHB) }\end{array}$ & $\begin{array}{l}\text { An efficient hospital can } \\
\text { guide hospital managers, } \\
\text { assist policy, and im- } \\
\text { prove the performance } \\
\text { of health services na- } \\
\text { tionally and internation- } \\
\text { ally. }\end{array}$ \\
\hline 4 & $\begin{array}{l}\text { Evaluation of } \\
\text { bed utilization } \\
\text { performance of } \\
\text { hospital depart- } \\
\text { ments in turkey } \\
\text { with grey rela- }\end{array}$ & 2019 & Turkey & $\begin{array}{l}\text { The average clinical ALS } \\
\text { and BTR indicators were } \\
67.3 ; 5.6 \text { and } 63.4\end{array}$ & $\begin{array}{l}\text { 1. Bed occupancy rate (BOR) } \\
\text { 2. The average length of stay } \\
\text { (ALS) } \\
\text { 3. Bed turnover rate (BTR) }\end{array}$ & $\begin{array}{l}\text { The hospital's bed utili- } \\
\text { zation performance has a } \\
\text { positive impact on the } \\
\text { hospital's financial suc- } \\
\text { cess. A significant por- } \\
\text { tion of the cost of oper- }\end{array}$ \\
\hline
\end{tabular}


tional analysis

[19] ating in hospitals is due to unnecessary patient hospitalization. To reduce hospital costs, patient beds need to be used optimally. Hence, hospital managers should regularly audit bed utilization.

\begin{tabular}{|c|c|c|c|c|c|c|}
\hline 5 & $\begin{array}{l}\text { The efficient of } \\
\text { beds used based } \\
\text { on graphic Bar- } \\
\text { ber Johnson at } \\
\text { Semen Padang } \\
\text { Hospital in } 2017 \\
\text { [20] }\end{array}$ & 2019 & Indonesia & $\begin{array}{l}\text { Statistical analysis results } \\
\text { obtained total BOR } 60 \% \text {, } \\
\text { BTR } 67 \text { times, TI } 2 \text { days and } \\
\text { ALoS } 3 \text { days. The highest } \\
\text { value of bed occupancy rate } \\
\text { is } 66 \% \text { on August. }\end{array}$ & $\begin{array}{l}\text { 1. Occupancy rate (BOR) } \\
\text { 2. Average length of stay (ALoS) } \\
\text { 3. Turnover interval (TI) } \\
\text { 4. Bed turnover (BTR) }\end{array}$ & $\begin{array}{l}\text { Average length of stay } \\
\text { ( } 3 \text { days) and bed turno- } \\
\text { ver rate ( } 67 \text { times) are } \\
\text { not efficient. }\end{array}$ \\
\hline 6 & $\begin{array}{l}\text { Is bed turnover } \\
\text { rate a good met- } \\
\text { ric for hospital } \\
\text { scale efciency? } \\
\text { A measure } \\
\text { of resource utili- } \\
\text { zation rate } \\
\text { for hospitals } \\
\text { in Southeast } \\
\text { Nigeria [21] }\end{array}$ & 2020 & $\begin{array}{l}\text { Southeast } \\
\text { Nigeria }\end{array}$ & $\begin{array}{l}\text { The hospitals' mean bed } \\
\text { occupancy rate was as low } \\
\text { as } 42.14 \% \text {, far below stand- } \\
\text { ard benchmark of } 80-85 \% \text {. } \\
\text { The mean average length of } \\
\text { stay was as high as } 8.15 \\
\text { days and observed mean bed } \\
\text { turnover was } 21.27 \text { pa- } \\
\text { tients/bed/ year. }\end{array}$ & $\begin{array}{l}\text { 1. Bed occupancy rate (BOR) } \\
\text { 2. Average length of stay (ALS) } \\
\text { 3. Bed turnover rate (BTR) } \\
\text { 4. Turnover interval (TI) }\end{array}$ & $\begin{array}{l}\text { Factors that are effective } \\
\text { for assessing hospital } \\
\text { performance or as- } \\
\text { sessing efficiency in } \\
\text { resource utilization are } \\
\text { hospital bed turnover } \\
\text { rate (BTR), bed occu- } \\
\text { pancy rate (BOR), and } \\
\text { average length of stay } \\
\text { (ALS). }\end{array}$ \\
\hline 7 & $\begin{array}{l}\text { Levels, trends } \\
\text { and determinants } \\
\text { of technical effi- } \\
\text { ciency of general } \\
\text { hospitals in } \\
\text { Uganda: data } \\
\text { envelopment } \\
\text { analysis and } \\
\text { Tobit regression } \\
\text { analysis [10] }\end{array}$ & 2020 & Uganda & $\begin{array}{l}\text { There was no statistically } \\
\text { significant difference in the } \\
\text { efficiency scores of public } \\
\text { and private hospitals. The } \\
\text { results of statistical meas- } \\
\text { urements were found to be } \\
\text { significant determinants of } \\
\text { efficiency at the 5\% level, } \\
\text { namely hospital size, geo- } \\
\text { graphic location, and train- } \\
\text { ing status. }\end{array}$ & $\begin{array}{l}\text { Analysis technique: } \\
\text { 1. Hospital ownership } \\
\text { 2. Hospital size } \\
\text { 3. Proportion of qualified staff } \\
\text { 4. Geographical location } \\
\text { 5. Bed occupancy rate } \\
\text { 6. Training status } \\
\text { 7. Outpatient visit ratio to total } \\
\text { inpatient days } \\
\text { 8. Average length of stay }\end{array}$ & $\begin{array}{l}\text { The } 69 \% \text { average varia- } \\
\text { ble returns to scale tech- } \\
\text { nical efficiency indicates } \\
\text { that the hospitals could } \\
\text { generate the same vol- } \\
\text { ume of outputs using } \\
31 \%(3439) \text { less staff } \\
\text { and } 31 \% \text { (3539) less } \\
\text { beds. }\end{array}$ \\
\hline 8 & $\begin{array}{l}\text { The efficiency in } \\
\text { the ordinary } \\
\text { hospital bed } \\
\text { management: A } \\
\text { comparative } \\
\text { analysis in four } \\
\text { European coun- } \\
\text { tries before the } \\
\text { COVID-19 out- } \\
\text { break [9] }\end{array}$ & 2021 & $\begin{array}{l}\text { four Eu- } \\
\text { ropean } \\
\text { countries: } \\
\text { France, } \\
\text { Germany, } \\
\text { Italy and } \\
\text { Spain }\end{array}$ & $\begin{array}{l}\text { In particular, the high avail- } \\
\text { ability of beds in the majori- } \\
\text { ty of the France regions } \\
\text { paired with the low occu- } \\
\text { pancy rate and high turnover } \\
\text { interval led these regions to } \\
\text { have a high number of } \\
\text { available beds. }\end{array}$ & $\begin{array}{l}\text { Hospital bed management: } \\
\text { 1. Beds Occupancy Rate (BOR) } \\
\text { 2. Average Length Of Stay (Av- } \\
\text { LOS) } \\
\text { 3. Turnover Interval (TOI) } \\
\text { 4. Beds Turn Over (BTO) } \\
\text { Manage the health resources: } \\
\text { 1. Medical professionals } \\
\text { 2. Equipment } \\
\text { 3. Hospital beds } \\
\text { 4. General practitioners } \\
\text { 5. Policy }\end{array}$ & $\begin{array}{l}\text { Concentration of hospi- } \\
\text { talized patients and scar- } \\
\text { city of beds put pressure } \\
\text { on improving hospital } \\
\text { efficiency }\end{array}$ \\
\hline
\end{tabular}

Hospital is a health service institution that provides complete individual health services that provide inpatient, outpatient, and emergency services. Hospitals are obliged to provide safe, quality, anti-discriminatory, and effective health services by prioritizing the interests of patients in accordance with hospital service standards [7] [22] [23] [24]. To assess the quality of hospital services, the National Health Services (NHS) introduces 6 (six) requirements in assessing the performance of hospital services, one of which is efficiency [25].

The efficiency of hospital management can be broadly seen from two aspects, namely the medical aspect, reviewing efficiency from the point of view of the quality of medical services, and from the economic perspective, reviewing efficiency from the point of view of the utilization of existing facilities. Assessment of service efficiency is an assessment of managerial ability in order to process sources of funds, personnel, equipment, and technology in order to provide services to patients, so in this sense it includes the notion of managerial ability, processing sources of funds, personnel, equipment and technology, and for patient care [8] [26]. The availability of hospital beds and efficiency in the management of health resources play an important role in determining the space for maneuvering health facilities in the event of an emergency situation, this is in line with the results of the analysis of the articles conducted [9] [17]. The hospital's bed utilization performance has a positive impact on the hospital's fi-nancial success. A significant portion of the cost of operating in hospitals is due to unnecessary patient hospitalization [19] [27].

Based on the systematic review conducted, various factors that can affect the efficiency of health services in hospitals are obtained, namely: Organizational factors, such as hospital-physicians integration level, teaching status, and market competition with hospital inefficiency, and status technology level. Manage the health resources factors, such us medical professionals, equipment, hospital beds, general practitioners, policies, management, proportion of qualified staff, training status. And then, technical efficiency factor that are hospi- 
tal ownership, Outpatient - inpatient ratio (OPIPR), The average length of stay (ALOS), The ratio of administrative to health employees (ADHR), Hospital size (dummy) (SIZE), Hospital location (dummy) (LOC), The proportion of refugees living in the governorate (REFP), Number of hospital beds per 10,000 inhabitants (HPFP), The available primary care centers per 10,000 inhabitants (PRC), The percentage of public hospital beds (PPHB), bed occupancy rate (BOR), average length of stay (ALS), bed turnover rate (BTR) and turnover intervals (TI), Average Length Of Stay (AvLOS), Turnover Interval (TOI), Beds Turn Over (BTO).

\section{Conclusion}

The efficiency of health services in hospitals is the basis for obtaining a wider patient base and resulting in the quality of these services. Various factors obtained from the results of a systematic review are categorized into organizational factors, health resource factors, and technical efficiency factors.

\section{References}

[1] E. Rustiyanto, Statistik Rumah Sakit untuk Pengambilan Keputusan. Yogyakarta: Graha Ilmu, 2010.

[2] Menteri kesehatan RI, Undang-Undang Nomor 36 Tahun 2009 tentang Kesehatan, vol. 4, no. 3. 2009.

[3] D. Hartono, Indikator Penampilan Penilaian Rumah Sakit. Jakarta: Cermin Dunia Kedokteran, 1991.

[4] I. . Pohan, Jaminan Mutu Layanan Kesehatan Dasar-Dasar Pengertian dan Penerapan. Jakarta: EGC, 2007.

[5] Putri Lasayka Fidora, “Analisis Efisiensi Pelayanan Rawat Inap Menurut Grafik Barber-Johnson di RSUD Tanjung Pura Kabupaten Langkat Tahun 2019,” Skripsi, 2020.

[6] R. Sidiq and R. Afrina, "Kajian Efisiensi Pelayanan Rumah Sakit,” Idea Nurs. J., vol. 8, no. 1, pp. $29-34,2017$.

[7] Peraturan Presiden RI, Rumah Sakit Nomor 44 Tahun 2009, vol. 4, no. 3. Indonesia, 2009.

[8] B. Sabarguna, Quality Assurance Pelayanan Rumah Sakit. Jakarta: Sagung Seto, 2008.

[9] F. Pecoraro, D. Luzi, and F. Clemente, "The efficiency in the ordinary hospital bed management: A comparative analysis in four European countries before the COVID-19 outbreak," PLoS One, vol. 16, no. 3 March, pp. 1-18, 2021, doi: 10.1371/journal.pone.0248867.

[10] R. Ayiko et al., "Levels, trends and determinants of technical efficiency of general hospitals in Uganda: Data envelopment analysis and Tobit regression analysis," BMC Health Serv. Res., vol. 20, no. 1, pp. 1-12, 2020, doi: 10.1186/s12913-020-05746W.

[11] I. A. B. Kemal N. Siregar, Dewi Nirmala Sari, Fika Minata Wathan, Delmaifanis, Rikawarastuti, Langkah Demi Langkah Systematic Literature Review dan Meta-Analysis di Bidang Kesehatan. Depok: Universitas Indonesia Publishing, 2021.

[12] I. G. Dharma Utamayasa, "Efect Physical Activity and Nutrition During The Covid-19 Pandemic," Int. J. Eng. Sci. Inf. Technol., vol. 1, no. 1, 2021, doi: 10.52088/ijesty.v1i1.58.

[13] Z. Zakiyuddin and F. Reynaldi, "The Phenomenon of 'Badapu' Tradition with Nutritional Status in Postpartum Mothers in West Aceh,” Int. J. Eng. Sci. Inf. Technol., vol. 1, no. 1, 2021, doi: 10.52088/ijesty.v1i1.42.

[14] M. Srimayarti, B. N., Siregar, K. N., \& Rahmaniati, "Peran Personal Health Record (PHR) dalam Pengelolaan Diabetes Melitus Tipe 2. Jurnal Manajemen Kesehatan Yayasan RS. Dr. Soetomo, 5(1), 68-83.,” 2019.

[15] S. Baqaruzi, A. Afit Miranto, and D. Wahyuda, "The Effect of Halbach Array Configuration on Permanent-Magnet Synchronous Generator (PMSG) Outer-Runner,” Int. J. Eng. Sci. Inf. Technol., vol. 1, no. 2, 2021, doi: 10.52088/ijesty.v1i2.50.

[16] G. Moradi, B. Piroozi, H. Safari, N. Esmail Nasab, A. Mohamadi Bolbanabad, and A. Yari, "Assessment of the efficiency of hospitals before and after the implementation of health sector evolution plan in Iran based on Pabon Lasso model," Iran. J. Public Health, vol. 46, no. 3, pp. 389-395, 2017.

[17] H. Leleu, M. Al-Amin, M. Rosko, and V. G. Valdmanis, "A robust analysis of hospital efficiency and factors affecting variability," Heal. Serv. Manag. Res., vol. 31, no. 1, pp. 33-42, 2018, doi: 10.1177/0951484817730537.

[18] W. I. M. Sultan and J. Crispim, "Measuring the efficiency of Palestinian public hospitals during 2010-2015: An application of a two-stage DEA method," BMC Health Serv. Res., vol. 18, no. 1, pp. 1-17, 2018, doi: 10.1186/s12913-018-3228-1.

[19] A. YİĞİT, "Evaluation of Bed Utilization Performance of Hospital Departments in Turkey With Grey Related Analysis," Int. J. Heal. Serv. Res. Policy, vol. 4, no. 3, pp. 173-183, 2019, doi: 10.23884/ijhsrp.2019.4.3.03.

[20] S. Mandia, "The efficient of beds used based on graphic Barber Johnson at Semen Padang Hospital in 2017," Int. J. Community Med. Public Heal., vol. 6, no. 12, p. 5071, 2019, doi: 10.18203/2394-6040.ijcmph20195446.

[21] H. E. Aloh, O. E. Onwujekwe, O. G. Aloh, and C. J. Nweke, "Is bed turnover rate a good metric for hospital scale efficiency? A measure of resource utilization rate for hospitals in Southeast Nigeria," Cost Eff. Resour. Alloc., vol. 18, no. 1, pp. 1-8, 2020, doi: 10.1186/s12962-020-00216-w.

[22] D. Z. Yasli, D. Leonard, and B. N. Srimayarti, "Analisis Kelengkapan Formulir A ( Evaluasi Awal MPP ) D an Formulir B ( Catatan Implementasi ) Pasien Rumah Sakit,” vol. 6, no. 1, pp. 31-41, 2021.

[23] I. S. Devid Leonard, "Penerapan Kegiatan Analisa Kuantitatif Rekam Medis Rawat Inap pada Ruang Marwa di RSI Siti Rahmah Padang," Adm. Heal. Inf. J., vol. 1, no. 1, pp. 27-35, 2020.

[24] M. Ayung Tama, M. I. Setiawan, and S. Budi Wasono, "Analysis Of The Performance East Circle Road Of Sidoarjo," Int. J. Eng. Sci. Inf. Technol., vol. 1, no. 2, 2021, doi: 10.52088/ijesty.v1i2.53.

[25] M. Giancotti, A. Guglielmo, and M. Mauro, Efficiency and optimal size of hospitals: Results of a systematic search, vol. 12, no. 3. 2017.

[26] S. Kumari and A. Harikrishnan, "Importance of Financial literacy For Sustainable Future Environment: A Research Among People In Rural Areas With Special Reference To Mandi District,Himachal Pradesh,” Int. J. Eng. Sci. Inf. Technol., vol. 1, no. 1, 2021, doi: 10.52088/ijesty.v1i1.36.

[27] M. Mahfut, M. V. Treesya Panjaitan, S. Wahyuningsih, T. Tripeni Handayani, and S. Sukimin, "Identification of Disease and Efforts to Protect Natural Orchid Plants Against Fungi Infection in the Liwa Botanical Garden," Int. J. Eng. Sci. Inf. Technol., vol. 1, no. 1, 2021, doi: 10.52088/ijesty.v1i1.39. 